\title{
APRESIASI MASYARAKAT TERHADAP FILM ISLAMI AYAT-AYAT CINTA (AAC)
}

\author{
Mulyono \\ Fakultas Tarbiyah dan Staf Lembaga Penelitian Universitas Islam Negeri UIN Malang. Jalan \\ Gajayana 50 Malang 65114 Telp. 0341-551354, 558882 Faks. 0341-572533, 0341-558882 \\ e-mail:mulyono-ma@yahoo.com
}

\section{Abstract}

AAC film is a new phenomenon in Indonesian film industry. Since the first week of its launching in movie theatres, the film directed by Hanung Bramantyo has got a great appreciation from society, especially teenagers. AAC is not only a new motivation for the lovers of Islamic fictions and the society who need Islamic programs, but also an inspiration concerning Islamic schools, learning society, AlQur'an, Hadist, Al_azhar, Cairo, Muslim scholars, praying, mosque, and including the negative impression of Islam. AAC is adapted from the best seller novel Ayatayat Cinta by Habiburrohman El-Shyrozy that tells about the love story of an Indonesian student who studies in Egypt, in Al-Azhar university. Both the novel and the film have high missionary endeavors, therefore works of Islamic culture have multi-functions, at least as an entertainment and a guidance as well. Consequently, it is natural that the society will give a high appreciation for both the novel and the film.

Keywords: Appreciation, Islamic film, Ayat Ayat Cinta

\section{Pendahuluan}

Kesuksesan sutradara Hanung Bramantyo mengangkat Ayat Ayat Cinta (AAC) ke layar kaca (film) pat ut diacungi jempol. Novel religius best seller karya Habiburrahman El Shirazy edisi pertama Desember 2004 - tersebut berhasil disebut menjadi film bernuansa religius yang apik dan mencerahkan sehingga layak mendapatkan apresiasi masyarakat Indonesia yang begitu luas.

Film merupakan bagian penting dari karya budaya bangsa yang penggarapannya melalui serangkaian gambar yang diproyeksikan secara 
cepat ke layar. Rangkaian gambar ini akan memberikan ilusi pergerakan yang teratur, lancar, dan terus-menerus. Gerak dan lakon yang diangkat dari kehidupan, kewajaran dalam menyampaikan dialog, adanya konflik sikap dan sifat manusiawi, adanya setting, kesatuan ide atau kejadian dan sebagainya. Ada hubungan kesamaan yang sangat jelas antara karya sastra dengan karya film, mereka bersama-sama mengangkat kehidupan ini yang satu ke atas pena dalam bentuk untaian kalimat, yang lainnya merekam leat film yang kemudian menyorotkannya ke layar perak (Effendy, 2002: 36).

Film berbeda dengan pertunjukan langsung di atas panggung seperti drama (repertoire), ketoprak, ludruk, wayang orang, lawakan; yang kemudian direkam oleh sebuah alat yang kita kenal dengan kamera. Ada perbedaan yang sangat jelas film dengan pertunjukkan panggung; dialog, sendi atau unsur-unsur cerita dan bahan-bahan visual lainnya dimana hubungan penonton dengan apa yang ditonton sangat jelas sekali. Dalam suatu pementasan drama (teater) penonton terpisah secara emosi dari para pemain, sedangkan pada film tidaklah demikian. Hal ini dikarenakan adanya teknik pengambilan gambar, sudut angle yang berpindah-pindah, close up, cutting dan sebagainya. Di mana penonton dalam fokus dan sudut angle (sudut pandangnya) telah dibimbing langsung oleh sutradara dan kamerawan. Kalau dalam drama ini suatu hal yang sangat mustahil. Ia bebas memfokuskan pada apa yang disaksikannya di atas pentas. Tapi ia juga tidak bebas dan hanya terikat pada satu sudut pandang saja dimana ia berada (Mulyono \& Nurul Habibah, 2008: 6).

Louis dan Auguste Lumiere adalah dua bersaudara dari Perancis yang menciptakan film pertama dengan alat yang bernama cinematographe. Alat ini berfungsi sebagai kamera sekaligus proyektor. Mereka menampilkannya ke publik pada 28 Desember 1895. Film yang ditampilkan masih berupa adegan pendek tak bersuara (bisu) dengan jalan cerita tertulis di layar. Musik pengiring film adalah musik langsung (live) yang dimainkan oleh seorang pianis. Musik disesuaikan dengan adegan yang terjadi di layar. Apabila adegan kejar-kejaran, maka sang pianis akan memainkan musik cepat, dan sebagainya. 
Sedangkan film menjadi sebuah industri muncul di Prancis. Perusahaan Pathe Freres sejak 1902 membuat fasilitas produksi film dan membuka agen penjualan di berbagai negara. Harus diingat saat itu durasi film masih kurang dari 1 jam per judul film (Effendy, 2002: 76).

Sejak produksi film pertama tahun 1902, film telah mengalami perkembangan yang luar biasa. Apalagi sejak munculnya alat kamera yang disebut handycam maka pembuatan film semakin mudah dan dapat dilakukan oleh siapa saja, kapan saja dan di mana saja. Di samping itu, film telah digunakan dalam hampir semua segi kehidupan manusia, sebagai hiburan, propaganda, menayangkan sejarah, prediksi zaman masa depan, bisnis, periklanan, politik, lingkungan hidup, pendidikan hingga sebagai alat dakwah. Di antara sekian misi yang menggunakan media film, yang akhirakhir ini semakin semarak adalah penggunaan film sebagai media dakwah. Film yang mengandung nilai tontonan atau hiburan sekaligus tuntunan sebagai media dakwah yang sekarang lagi menjadi trend adalah film Ayat Ayat Cinta. Artikel singkat ini mengkaji tentang apresiasi masyarakat terhadap film. religius Ayat Ayat Cinta (AAC).

\section{Perkembangan Film/Sinetron Islami di Indonesia}

Film pertama di Indonesia dibuat pada tahun 1926 dengan judul Loetoeng Kasaroeng, namun pembuatnya masih orang Belanda. Adapun film pertama yang dibuat oleh orang Indonesia sendiri berjudul Darah dan Doa, yang diproduseri dan disutradarai oleh Usmar Ismail, pada tahun 1950. Hari Film Nasional sendiri diperingati pada 30 Maret, yang dijadikan sebagai tanggal lahirnya perusahaan film Nasional pertama (NV). Festival Film Indonesia (FFI) pertama diselenggarakan pada tanggal 5 April 1955 dengan film yang berjudul Lewat Jam Malam karya Usmar Ismail yang menjadi film terbaik. Pada tahun 1960-an, perfilman Indonesia mengalami kesulitan, akibat masuknya film impor, berkurangnya bioskop, hingga situasi politik saat itu.

Pada dekade 1970-an, film Indonesia mengalami kegairahan kembali. Lebih dari 600 judul film diproduksi pada masa itu. Pada 1980-an, produksi film Indonesia lebih meningkat lagi menjadi lebih dari 700 judul film. Jumlah 
aktor dan aktris serta penonton meningkat pula. Namun film paling monumental dalam jumlah penonton adalah Penghianatan G-30S/PKI. Film ini ditonton hampir 700.000 orang (meski campur tangan pemerintah Orde Baru tidak bisa diabaikan). Pada akhir 1980-an, banyak gedung bioskop konvensional yang diubah menjadi sinepleks oleh Group 21 sebagai pemiliknya (Effendy, 2002: 54).

Pada 1990-an, kondisi film Indonesia mengalami keterpurukan yang telah terjadi sejak akhir 1980-an. Beberapa sebab, seperti ; menjamurnya kepemilikan video, banjirnya film impor hingga tema film yang monoton menjadi penyebabnya. Namun saat itu pula muncul Garin Nugroho sebagai sutradara Indonesia langganan festival film dunia. Pada awal abad ini, didorong kehadiran teknologi yang mempermudah orang membuat film dan tema-tema menarik, film Indonesia mulai dilirik oleh penonton. Beberapa film seperti Jelangkung, Petualangan Sherina, dan Ada Apa Dengan Cinta?, dan Kiamat Sudah Dekat; menjadi harapan baru masa depan film Indonesia.

Di samping itu sejak pertengahan tahun 2004, beberapa televisi di Indonesia dibanjiri sinetron religius bertajuk "Ilahi'. Diawali dengan sukses TPI menayangkan serial Rahasia Ilahi, yang konon diilhami dari kisah-kisah nyata dalam majalah Hidayah, stasiun TV swasta lain kemudian mengikuti jejak TPI. SCTV dengan Astaghfirullah dan Kuasa Ilahi; Trans TV dengan Taubat, Insyaf, dan Istighfar. Lativi dengan Azab.Ilahi, Pada-Mu Ya Rabb, dan Sebuah Kesaksian; RCTI dengan Tuhan Ada Di Mana-mana; ANTV dengan Azab Dunia dan Jalan ke Surga; TV7 dengan Titik Nadir; dan TPI sendiri dengan Takdir Ilahi, Allah Maha Besar, dan Kehendak-Mu (Mulyono \& Habibah, 2008: 10).

Sinetron religius semacam ini ternyata mampu mendongkrak peringkat stasiun penayangnya. Rahasia Ilahi dan Takdir Ilahi, misalnya, mampu menjadi kontributor terbesar yang mendongkrak posisi TPI dari tujuh besar ke posisi tertinggi di Indonesia. Tak heran jika kemudian hampir semua stasiun TV menayangkan sinetron sejenis. Berdasarkan sumber cerita, sinetron itu dikategorikan menjadi dua, yaitu: Pertama, Sinetron yang didasarkan pada kisah nyata. TPI dengan Rahasia Ilahi didasarkan pada kisah yang pernah dimuat majalah Hidayah dan Allah Maha Besar 
didasarkan pada pengalaman nyata penceritanya. SCTV dengan Astaghfirullah didasarkan atas kisah nyata di majalah Ghaib. Trans TV dengan Taubat mengambil cerita dari majalah Insting. Lativi dengan Azab Ilahi dan Sebuah Kesaksian didasarkan atas narasi atau kesaksian orangorang yang mengalami atau menyaksikan langsung kejadian yang dituturkan dalam sinetron tersebut. Kedua, Sinetron yang ide ceritanya diambil dari sumber-sumber kisah klasik, terutama dari hadits-hadits yang dianggap sahih atau dari buku kumpulan cerita yang juga diambil dari kitab-kitab klasik. Sebagian besar hadits yang dijadikan rujukan dalam sinetron terutama Takdir Ilahi di TPI adalah hadits Bukhari Muslim yang dimuat dalam kitab Mi'ah Qishshah wa Qishshah fi Anis Al-Shalihin wa Samir Al-Muttaqin karya Muhammad Amin al-Jundi al-Muttaqin dan kitab Madarij Al-Salikin karya Ibnu Qayyim al-Jauziah.

Dalam iklannya, TPI dengan jelas mengatakan bahwa Takdir Ilahi merupakan "aktualisasi dari peristiwa yang pernah terjadi di zaman Rasulullah". Sajiannya tentu sudah disesuaikan dengan perkembangan zaman dan formatnya dibuat lebih modern. Untuk lebih menyakinkan penonton, di akhir tayangan sinetron ini, TPI menghadirkan seorang da'i, $\mathrm{KH}$. Ali Mustafa Yaqub, yang memberi penafsiran dan hikmah yang dapat diambil dari tayangan sinetron itu. Meskipun masih terkesan berupa tafsir literal dan lebih menekankan kesalehan ritual, komentar para kyai dan da'i ini agaknya menarik perhatian penonton, setidaknya dapat menambah "kepercayaan" penonton bahwa tayangan tersebut benar-benar bertujuan dakwah dan bukan bisnis semata.

Sampai di sini sebenarnya tak ada persoalan. Bahkan sekilas sinetronsinetron itu dapat memberi semacam kelegaan terhadap dahaga rohani yang mungkin dialami oleh sebagian orang Indonesia. Namun, jika diperhatikan lebih seksama, kita akan menjumpai beberapa kejanggalan: alur cerita yang tak logis, penulisan skenario yang terkesan mengejar waktu dan nguber setoran, dan penafsiran agama yang membuat umat terikat pada simbol-simbol formal tanpa pemaknaan lebih mendalam atas pesanpesan kemanusiaan yang terdapat dalam setiap agama (Wibowo, 2008: 75). 
Dalam konteks tersebut tidak berlebihan jika dikatakan bahwa agama dalam bentuk tayangan sinetron semacam ini telah beralih fungsi menjadi ideologi dalam pengertian Marxis, yaitu sebagai penyembunyian realitas dari persoalan konkret sebenarnya yang dihadapi masyarakat. Marx memahami realitas sebagai praksis aktivitas produktif manusia dan ideologi sebagai penentangan terhadap praktis. Lebih jauh, Marx mengungkapkan bahwa "sumber yang sebenarnya dari aktivitas manusia adalah praksis dan bukan kesadaran" (Wibowo, 2008: 101).

Penyembunyian atau distorsi atas realitas itu kemudian dikemas sedemikian rupa dengan ayat-ayat al-Qur'an yang sengaja dikutip untuk mendukung peristiwa yang ditayangkan dalam sinetron-sinetron itu. Artinya, telah terjadi semacam "manipulasi" atas teks kitab suci ketika ayatayat yang mendukung "pandangan dunia" sinetron itu dikutip dan dijadikan sebagai pembenar dan pendukung. Sementara itu, ayat-ayat yang bernada lain - yang sudah pasti terdapat dalam al-Qur'an - tidak dikutip karena tak sejalan dengan "pandangan - dunia" sinetron tersebut.

Namun, terlepas dari semua kelemahan tersebut, hampir semua pihak sepakat bahwa perkembangan sastra, film maupun sinteron Islami sejak era 2000-an mengalami perkembangan yang pesat. Dan tentunya perkembangan ini akan mendapatkan apresiasi yang tinggi dari masyarakat seiring dengan perkembangan kehidupan agamis masyarakat Indonesia.

\section{Apresiasi Masyarakat terhadap Film Ayat Ayat Cinta (AAC)}

Novel best seller Ayat Ayat Cinta karya Habiburrahman El-Shirazy menjadi semakin fenomenal setelah diangkat ke layar lebar pada awal 2008. Ayat-ayat Cinta yang bertema religi menjadi nafas baru bagi masyarakat Indonesia. Romantisme gaya Islam yang santun membuat film ini memiliki nilai plus dibanding film romantisme kebanyakan. Ditambah pemeran tokohtokoh Ayat Ayat Cinta adalah artis dengan kualitas peran yang tak diragukan. Tak heran bila Ayat Ayat Cinta menjadi novel dan film terlaris sepanjang sejarah Indonesia (Hefni, 2008 : 3).

Bagitu kentalnya nuansa religius dan tuntunan kebaikan dalam AAC, sampai-sampai Ketua Umum PP Muhammadiyah Din Syamsuddin 
merekomendasikan AAC sebagai tontonan wajib umat muslim (Wibowo, 2008: 90). Bahkan Presiden Susilo Bambang Yudoyono, Wakil Presiden Yusuf Kalla dan sejumlah pejabat tinggi menyempatkan melihat film religius tersebut, Sebagaimana diberitakan oleh Republika (Minggu, 30 Maret 2008), air mata presiden pun menetes. "Saya menyeka air mata berkali-kali. Pesannya sampai," ucap Presiden Susilo Bambang Yudhoyono usai menonton film Ayat Ayat Cinta (AAC) di Bioskop Plaza EX, Thamrin, Jakarta Pusat, Jumat (28/3/2008) malam.

Terlepas dari cerita yang dituturkan dan cara sutradara menuangkan tulisan AAC dalam film tersebut, Presiden menyampaikan adanya satu pesan yang penting untuk dipetik: Film dari novel karya Habiburrahman El Shirazy ini memperlihatkan nilai peradaban Islam dan pendidikan.

Film ini, menurut Presiden, menunjukkan bagaimana mengapresiasikan nilai-nilai yang lebih dari sekadar simbol-simbol sehingga masyarakat dunia dapat hidup berdampingan dalam perbedaan. Ia juga menyebutkan, saat ini Indonesia bersama sejumlah negara di dunia terus berupaya membangun kebersamaan guna menghindari perpecahan.

'Islam banyak disalahartikan. Ini adalah bagian pelajaran bagi semua Muslim bahwa Islam adalah peace, love, tolerance, and harmony. Islam benci kekerasan. Film ini merefleksikan hal ini," sambung Presiden yang saat itu menonton di Studio 1 pada barisan E didampingi Ibu Ani Yudhoyono dan seluruh anggota keluarganya (Republika, Minggu, 30 Maret 2008).

Dalam gelar acara menonton bareng Presiden itu, sebanyak 53 perwakilan negara sahabat, 107 undangan, dan para menteri pun ikut menyaksikan film karya sutradara Hanung Bramantyo ini. Tak ketinggalan, para pemeran dalam film itu pun hadir bersama dengan produser film Manooj Punjabi yang digawangi perusahaan MD Picture.

Dalam acara itu, satu bioskop di lantai dua Plaza EX yang terdapat empat studio dan dua studio premiere dikosongkan. Namun, hanya tiga studio saja yang digunakan untuk memutar film berdurasi sekitar dua jam itu. Film pun diputar sejak pukul 20.30 WIB.

Film yang bernuansa latar Timur Tengah itu dinilai Presiden merupakan karya anak bangsa yang membanggakan. SBY mengharapkan 
agar film ini menjadi tonggak bagi perfilman Indonesia. Dengan melihat larisnya film tersebut, pihaknya optimis dengan kebangkitan film Indonesia untuk menjadi tuan rumah di negeri sendiri. (Republika, Minggu, 30 Maret 2008)

Ditambah lagi, apresiasi masyarakat cukup menggembirakan. Itu terbukti dengan penuh-sesaknya bioskop-bioskop pada pemutaran perdana film AAC sejak 28 Februari 2008. Sebagaimana diberitakan di Harian Republika (Jum'at, 07 Maret 2008) animo masyarakat di beberapa kota besar begitu tinggi. Misalnya di kota Palembang untuk menyaksikan film Ayat Ayat Cinta (AAC) memasuki hari ke delapan pemutaran film religi tersebut di jaringan bioskop 21 masih sangat ramai dan pada pertunjukan Jum'at (7/3/2008) sempat membuat tiga calon penontonnya menderita lukaluka sehingga harus dilarikan ke rumah sakit, akibat pecahnya kaca pintu bioskop 21 yang terletak di lantai lima pusat perbelanjaan Internasional Plaza (IP) Palembang.

Bahkan, perempuan berjilbab yang jauh dari dunia hiburan selama ini menyempatkan diri untuk menikmati film romantis tersebut. MD Pictures menggandakan pita film itu hingga 100 kopi. Itu angka yang fantastis mengingat film Indonesia lain hanya dicetak 10-20 kopi, sementara film Hollywood 65-70 kopi (Yudisia, 2008: 11).

Sepintas, film AAC sebenarnya tidak jauh berbeda dengan film remaja -juga dewasa- pada umumnya. Di sana, disuguhkan tema-tema kemanusiaan, pluralisme, kesederhanaan, kesetiakawanan, serta romantisme percintaan yang mengharu biru. Hanya, film AAC mampu menampilkan romantisme percintaan yang dibesut dengan nilai-nilai ajaran Islam. (Wibowo, 2008: 17).

Sentuhan Hanung sebagai sutradara andal peraih Piala Citra 2004 dan 2007 terbukti lewat film ini. Baik dari aspek bahasa gambar yang sangat dikuasainya maupun tampilan bermacam detail yang "tertulis" menjadi terucap, atau hanya tervisualisasikan sesaat.

Pemilihan semua karakter seperti pada pemeran utama Fahri, Maria, Aisha, Nurul, dan Noura yang dominan juga sangat cocok dimainkan oleh aktor dan aktrisnya. Nilai plus bahkan diperlihatkan Carrisa Putri, 
sosok Maria, seorang gadis yang memendam cinta kepada Fahri sebagai tokoh utama, tampak hidup dalam dirinya.

Secara pasti, kehadiran film AAC memang mampu menciptakan genre dan warna baru di dunia perfilman Indonesia, khususnya film bernuansa religius. Apalagi, di tengah kejenuhan publik akan tontonan film-film religius yang digarap secara berlebih atau -dalam istilah Cak Nunfilm-film religius yang justru tidak religius lantaran memangkas nilai-nilai luhur agama Islam.

Mengapa demikian? Film-film religius picisan tersebut dipertontonkan sebagai media pengusir hantu, jin, setan, dan sebagainya. Bahkan, tak jarang disuguhkan pencitraan Tuhan yang kejam dan tanpa rasa welas-asih terhadap pendosa. Pencitraan tersebut berdampak buruk pada persemaian konsep teologis anak-anak, generasi muda, dan mereka yang awam terhadap agama Islam.

Karena itulah, mengangkat novel AAC ke layar lebar bukanlah hal baru, termasuk di Indonesia. Jauh sebelum jaringan bioskop sebanyak sekarang, pernah diputar film Roro Mendut, Atheis, Si Doel Anak Betawi, dan Salah Asuhan. Belakangan, ada Ca Bau Kan, Eiffel I'm In Love, Jomblo, Cintapucino, dan Mereka Bilang Saya Monyet (Wibowo, 2008: 27). Namun, dibandingkan dengan beberapa karya sastra yang sudah diangkat dalam layar lebar tersebut hingga saat ini, film AAC nampaknya masih dianggap fenomenal karena mendapatkan apresiasi yang begitu besar dari masyarakat luas.

\section{Inti Cerita dan Karakter Pelaku Film AAC}

Film AAC adalah kisah cinta. Tapi bukan cuma sekedar kisăh cinta yang biasa. Ini merupakan kisah tentang bagaimana menghadapi turunnaiknya persoalan hidup dengan cara Islam. Fahri bin Abdillah (Fedi Nuril) adalah pelajar Indonesia yang berusaha menggapai gelar masternya di Al Ahzar. Berjibaku dengan panas-debu Mesir. Berkutat dengan berbagai macam target dan kesederhanaan hidup. Bertahan dengan menjadi penerjemah buku-buku agama. Semua target dijalani Fahri dengan penuh antusiasme kecuali satu: menikah. Kenapa? Karena Fahri adalah laki-laki 
taat yang begitu 'lurus'. Dia tidak mengenal pacaran sebelum menikah. Dia kurang artikulatif saat berhadapan dengan mahluk bernama perempuan. Hanya ada sedikit perempuan yang dekat dengannya selama ini. Neneknya, ibunya dan saudara perempuannya. Betul begitu? Sepertinya pindah ke Mesir membuat hal itu berubah.

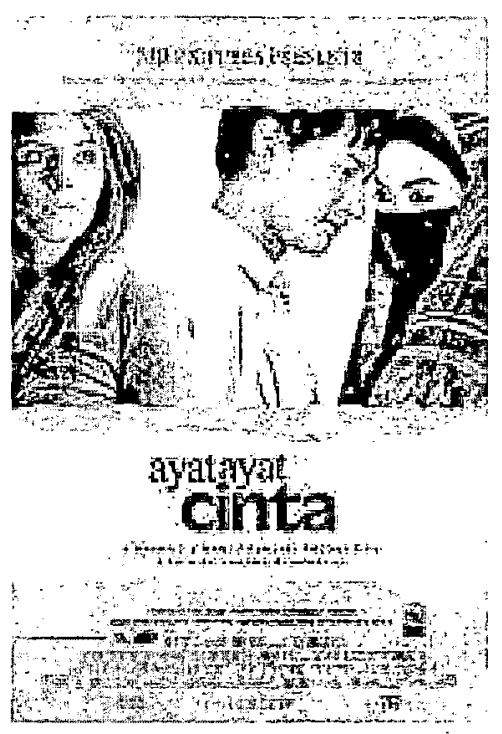

Gambar dalam CD Film Ayat Ayat Cinta

Tersebutlah Maria Girgis (Carissa Putri). Tetangga satu flat yang beragama Kristen Koptik tapi mengagumi Al Quran dan mengagumi Fahri. Kekagumannya berubah menjadi cinta. Sayang, cinta Maria hanya tercurah dalam diary saja. Lalu, ada Nurul (Melanie Putria), anak seorang kyai terkenal yang juga menuntut ilmu di Al Azhar. Sebenarnya Fahri menaruh hati pada gadis manis ini. Sayang, rasa mindernya yang hanya anak keturunan petani membuatnya tidak pernah menunjukkan perasaan apa pun pada Nurul. Sementara, Nurul pun menjadi ragu dan selalu menebak-nebak.

Setelah itu ada Noura, tetangga yang selalu disiksa ayahnya sendiri. Fahri berempati penuh pada Noura dan ingin menolongnya. Sayang hanya empati saja. Tidak lebih. Namun Noura mengharap lebih. 
Nantinya, hal ini menjadi masalah besar ketika Noura menuduh Fahri memperkosanya.

Terakhir muncullah Aisha, si mata indah yang menyihir Fahri. Sejak sebuah kejadian di metro, saat Fahri membela Islam dari tuduhan kolot dan kaku, Aisha jatuh cinta pada Fahri. Fahri pun juga tidak bisa membohongi hatinya.

Lalu bagaimana anak desa nan lurus itu menghadapi ini semua? Siapa yang dipilihnya? Bisakah dia menjalani semuanya dalam jalur Islam yang sangat dia yakini? (http://www.21cineplex.com). Secara lebih rinci karakter pelaku dalam film AAC dapat dijelaskan sebagai berikut:

1) Fahri bin Abdillah, 28 th (Fedi Nuril); Mahasiswa bersahaja yang memegang teguh prinsip hidup dan kehormatannya. Cerdas dan simpatik hingga membuat beberapa gadis 'jatuh hati'. Dihadapkan pada kejutan-kejutan menarik atas pilihan hatinya.

2) Aisha, 25 th (Rianti Cartwright); Mahasiswi asing keturunan Jerman dan Turki, cerdas, cantik dan kaya raya. Latar belakang keluarganya yang berliku mempertemukan dirinya dengan Fahri.

3) Maria Girgis, 26 th (Carissa Putri); Gadis Kristen Koptik yang jatuh cinta pada Islam. Dia menderita karena cinta yang teramat dalam kepada Fahri.

4) Noura bin Bahadur, 22 th (Zaskia Adya Mecca); Siksa telah menjadi bagian dalam hidupnya. Janin yang dikandungnya menjadikannya terobsesi" pada Fahri untuk menjadi ayah dari calon bayinya.

5) Nurul binti Ja'far Abdur Razaq, 26 th (Melanie Putria); Anak kyai besar di Jawa Timur. Dengan aura yang menenangkan, kecerdasan dan kualitasnya menyatukan segala kelebihannya, dia sangat percaya diri untuk meminang Fahri sebagai suaminya. (http:// www.ayatayatcintathemovie.com). 
Secara rinci karakteristik dan seluruh kru film AAC (Sumber: Film AAC, http://www.21cineplex.com, Novel AAC, 2008) dapat dijelaskan sebagai berikut:

\begin{tabular}{|c|c|}
\hline Judul Film & Ayat Ayat Cinta (A AC) \\
\hline Jenis Film & Drama \\
\hline Sutradara & Hanung Bramantyo \\
\hline Produser & Dhamoo Punjabi, Manoj Punjabi \\
\hline Executive Produser & Shania Punjabi \\
\hline Co Produser & Karan Mahtani \\
\hline Pemeran & $\begin{array}{l}\text { Fedi Nuril, Rianti Cartwright, Carissa Puteri } \\
\text { Melanie Putria, Zaskia Adya Mecca } \\
\text { Marini Burhan, Surya Saputra, Rudi Wowor, } \\
\text { Leroy Osmani, Hj. Mieke Wijaya, Oka Antora } \\
\text { Dennis Adhiswara, Sellen Fernandez }\end{array}$ \\
\hline Also Starting & Mochtar Sum, Sito Resmi, Amak Baldjun \\
\hline Casting & $\begin{array}{l}\text { Sanjay Mulani, Amelia Oktavia, } \\
\text { Ruth Damai Pakpahan }\end{array}$ \\
\hline Muke-up & Didin Syamsudin \\
\hline Costumes Designer & Retno Ratih Damayanti \\
\hline Art Director & Allan Sebastian \\
\hline Sound Disigner. & Satrio Budiono, Adimolana Mahmud \\
\hline Music Composer & Tya Subiakto \\
\hline Film Editor & Sastha Sunu \\
\hline $\begin{array}{l}\text { Director of } \\
\text { Photography }\end{array}$ & Faozan Rizal \\
\hline Screenplay & $\begin{array}{l}\text { Salman Aristo, Ginatri S. Noer , Habiburrahman } \\
\text { El-Shirazy }\end{array}$ \\
\hline Line Produser & $\begin{array}{l}\text { Ramesh Lakhiani, Tika Anggela Sandy } \\
\text { Muslich Iwid Wijaya }\end{array}$ \\
\hline Penayangan pertama & 28 Februari 2008 \\
\hline Durasi & 120 menit \\
\hline Setting Cerita & Kairo Mesir \\
\hline Bahasa & Indonesia, ada campuran Arab, Jerman, Inggris \\
\hline Rumah Produksi & MD Pictures Presents \\
\hline
\end{tabular}


AAC Unggul dalam Festival Film Bandung (FFB) 2008

Film Ayat Ayat Cinta (AAC) ternyata tidak hanya menorehkan sensasi dalam meraup jumlah penonton. Namun, film yang diadaptasi dari novel best seller Habiburrahman El Shirazy ini menawarkan daya pikat yang besar di Festival Film Bandung (FFB) 2008. Di festival ini, dua karya Hanung Bramantyo - AAC dan Get Married - saling bersaing ketat dengan meraih sembilan nominasi, termasuk persaingan keduanya meraih gelar Film Terpuji. Eddy D Iskandar, ketua umum FFB, mengatakan film AAC dalam festival tahun ini mendapatkan sembilan nominasi. Nominasi yang didapatkan film ini adalah Film Terpuji, Editing, Penata Artistik, Penata Kamera, Penata Musik, Penulis Skenario, Sutradara, Pemeran Utama Pria, dan Pemeran Utama Wanita Terpuji.

Film AAC yang hingga kini telah menembus jumlah penonton di atas 4 juta merupakan satu dari enam film nasional yang akan memperebutkan gelar Film Terpuji. Selain Get Married, para pesaing AAC adalah Kamulah Satu Satunya, Perempuan Punya Cerita, The Photograph, serta Mengejar Mas Mas.

Selain enam film tadi, Aming lewat film Get Married, Dwi Sasono (Mengejar Mas Mas), Fedi Nuril (Ayat Ayat Cinta), Rafi Ahmad (Love is Cinta), Vino G Sebastian (Radit dan Jani) dan WS Rendra (Lari dari Blora) akan memperebutkan tempat terpuji untuk Pemeran Utama Pria. Sedangkan beberapa nama, seperti Acha Septriasa (Love is Cinta), Carissa Puteri (Ayat Ayat Cinta), Dina Olivia (Mengejar Mas Mas), Kirana Larasati (Claudia), Nirina Zubir (Get Married), dan Shanty (The Photograph) bersaing untuk kategori Pemeran Utama Wanita," kata Eddy kembali mengumumkan.

Selanjutnya untuk sutradara, nama-nama yang tidak asing lagi di perfilman nasional akan memperebutkan gelar Sutradara Terpuji versi FFB, yaitu Hanung Bramantyo (Ayat Ayat Cinta), Hanny R Saputra (Love is Cinta), Nan Achnas (The Photograph), Rudy Soedjarwo (Mengejar Mas Mas), Hanung Bramatyo (Get Married), dan Dimas Djayadiningrat dalam film Quickie Express (Republika, Selasa, 8 April 2008). 


\section{AAC: Wajah Agama Tak Ketinggalan Zaman}

AAC bukan hanya angin segar bagi penikmat kisah fiksi Islam dan kalangan yang menginginkan tayangan "Islami", ia juga impulse bahwa dunia agama seperti pesantren, madrasah, masjid, Al-Quran, Hadits, Al Azhar, Kairo, ulama, dan segala sesuatu yang berbau religius bukanlah hal yang ketinggalan zaman. Bagi yang telah membaca AAC, kerinduan untuk bertemu Rasul, para sahabat, para ulama, dan tempat-tempat bersejarah kaum muslimin demikian mendesak dada (Yudisia, 2008: 25).

Menjadi tantangan bagi para penulis fiksi Islami, production house, dunia hiburan, dan semua pihak yang concern untuk bisa memberikan hiburan alternatif yang memiliki nilai universalitas Islam, tidak terkesan menggurui namun memiliki nilai dedaktis bagi penikmatnya. (Yudisia, 2008: 36).

Film Walisongo misalnya, tidak meledak karena penonton merasa jauh di luar bioskop dan hadir di majelis pengajian yang bertele-tele. Berbeda dengan AAC. Kebutuhan pemirsa kepada Islam, Rasulullah dan ulama, serta Al-Quran dan hadits justru dimunculkan dengan sentuhan indah semacam itu. Setelah keberhasilan film AAC, mata bangsa ini terbuka, diharapkan baik sutradara, produser, maupun production house tidak lagi alergi memproduksi tema-tema Islam yang sangat beragam bentuknya (Yudisia, 2008: 28).

Sebagaimana pendapat Deddy Mizwar bahwa kecenderungan masyarakat Indonesia kurang menyenangi terhadap tayangan televisi yang bermutu. Karena itu secara umum tayangan film/sinetron yang bermutu tidak banyak ditonton di televisi. Untuk itu, pembuatan film dan sinetron yang mengandung nilai-nilai religius dan pendidikan yang bermanfaat bagi kehidupan berbangsa dan bernegara yang sekaligus disenangi oleh penonton dari berbagai lapisan masyarakat seperti halnya kesuksesan film AAC tersebut patut didukung dan perlu mendapatkan apresiasi dari semua pihak termasuk kalangan akademis perguruan tinggi. 


\section{Simpulan}

Terlepas dari beberapa kekurangan, antara lain bobot pembuatan film AAC tidak sejajar dengan nilai dakwah yang dikandung dalam novel aslinya, namun hal itu tidak mengurangi apresiasi masyarakat terhadap karya film Islami tersebut. Dengan film AAC tersebut, Presiden SBY mengatakan bahwa sudah menjadi kewajiban seluruh umat Islam untuk menjelaskan kepada dunia bahwa Islam adalah agama yang cinta damai, penuh toleransi dan harmoni. Menurutnya, film terbaru karya sutradara muda Hanung Bramantyo itu merupakan salah satu cerminan mengenai Islam, mengenai bagaimana mengapresiasi nila-nilai lebih dari sekedar simbol-simbol sehingga masyarakat dunia dapat hidup berdampingan dalam perbedaan.

Susilo Bambang Yudoyono menegaskan bahwa ; sudah menjadi tanggung jawab bersama untuk menghindari benturan peradaban dan menjembatani perbedaan karena ada keperluan untuk menyatukan persamaan guna menghadapi tantangan global. Disebutkan juga bahwa saat ini Indonesia bersama sejumlah negara di dunia terus berupaya membangun kebersamaan guna menghindari perpecahan.

Pada kesempatan itu Presiden juga berharap agar film tersebut dapat menjadi tonggak baru kebangkitan dunia perfilman nasional sehingga film dalam negeri dapat menjadi tuan rumah di negeri sendiri. Menurut penilaian Presisden, Film AAC merupakan suatu economic creative, produk budaya dan merupakan suatu tumbuh kembang untuk menjadi sumber ekonomi baru di abad 21. Presiden berharap di masa mendatang akan hadir lebih banyak karya-karya seni yang luhur di Indonesia. Kepala Negara juga menyampaikan pujian terhadap sutradara, produser dan seluruh pemain film yang telah menghasilkan karya itu.

Pembuatan film ternyata pekerjaan yang perlu persiapan yang matang sejak ide dan sumber cerita, penyusunan cerita dalam bentuk skenario film hingga shoting yang melibatkan banyak orang yang memiliki keahlian masing-masing. Alur cerita, setting, keseriusan, dan kerja sama semua pihak merupakan modal penting dalam pembuatan film yang berbobot sebagaimana kesuksesan film AAC sehingga memiliki multi fungsi, minimal selain sebagai media tontonan (hiburan) sekaligus sebagai media tuntunan (pendidikan dan dakwah). 


\section{Daftar Pustaka}

Aries, Maspril. 7 Maret, 2008. Film Ayat-ayat Cinta Telan Tiga Korban. (Online), http://www.republika.co.id/, Diakses, Sabtu, 8 Maret 2008.

Effendy, Heru. 2002. Mari Membuat Film (Panduan Untuk Menjadi Produser). Yogyakarta: Panduan.

Habiburrahman, El Shirazy. 2008. Ayat Ayat Cinta. Jakarta Selatan: Republika.

http://www.21cineplex.com/movie.cfm?id=1819), Diakses Sabtu, 17-52008.

http://www.ayatayatcintathemovie.com/Diakses, Sabtu, 17-5-2008.

http://www.republika.co.id/mypustaka/buku detail.asp?id=44, Diakses, Sabtu, 17-5-2008.

Mulyono \& Nurul Habibah. 2008. The Power Religious Of Art - Seni Pementasan Religius: Tari, Drama, Teater, Film dan Sinetron Islami. Draff Buku. Malang: Lemlit UIN Malang.

Republika. 08 April, 2008. Ayat Ayat Cinta dan Get Married Bersaing di FFB.

Republika. Minggu, 30 Maret 2008

Republika. 29 Maret 2008. Presiden Nilai Film Ayat-ayat Cinta Dapat Jadi Media Siar Islam.

Tabloid Gema UIN Malang. Edisi 34, Maret-April, 2008.

Wibowo, Agus. 2008. Dilema Film Ayat-Ayat Cinta. (Online), (http:// www.jawapos.co.id, diakses 8 Maret 2008).

Yudisia, Sinta. 2008. AAC: Wajah Pesantren Tak Ketinggalan Zaman. (Online), ( http://www.jawapos.co.id, diakses 8 Maret 2008). 